\title{
The role of adiponectin and leptin in the treatment of ovarian cancer patients
}

\author{
Rola adiponektyny i leptyny w leczeniu chorych na raka jajnika
}

\author{
Grzegorz Słomian', Damian Nowak ${ }^{2}$, Marta Buczkowska ${ }^{3}$, Anna Głogowska-Gruszka ${ }^{3}$, Szymon Piotr \\ Słomian ${ }^{4}$, Wojciech Roczniak ${ }^{5}$, Szymon Janyga ${ }^{6}$, Przemysław Nowak ${ }^{3,7}$
}

${ }^{1}$ Oncological Ward, Independent Public Health Care Unit, Voivodeship Specialised Hospital No. 3, Rybnik, Poland

${ }^{2}$ Department of Physiology, School of Medicine with the Division of Dentistry, Zabrze, Poland

${ }^{3}$ Department of Toxicology and Addiction, Public Health Faculty, Bytom, Poland

${ }^{4}$ Urological Ward, Independent Public Health Care Unit, Voivodeship Specialised Hospital No. 3, Rybnik, Poland

${ }^{5} J a n$ Grodek Vocational State School, Medical Institute, Sanok, Poland

${ }^{6}$ Endocrinological Ward, Independent Public Health Care Unit, Voivodeship Specialised Hospital No. 3, Rybnik, Poland

${ }^{7}$ Department of Pharmacology, Opole University, Opole, Poland

\begin{abstract}
Introduction: Ovarian cancer is most frequently detected in the advanced stage. Although its pathogenesis is not fully elucidated, it is assumed that body susceptibility and hormonal disorders are responsible. The role of some cytokines as predictors in the treatment process is still investigated. The aim of the study was to determine the relationship of adiponectin and leptin with the disease severity and response to chemotherapy.

Material and methods: Forty-three ovarian cancer patients were treated by systemic treatment. Patients received 5-7 cycles of chemotherapy — paclitaxel/carboplatin with or without bevacizumab. Using standard ELISA kits before and after chemotherapy, adiponectin and leptin concentrations were determined in the blood serum.

Results: The average adiponectin concentration before chemotherapy was found to be $8.83 \pm 3.19 \mu \mathrm{g} / \mathrm{ml}$, as compared to $10.37 \pm 4.18 \mu \mathrm{g} / \mathrm{ml}$ (increase by $17.44 \%, \mathrm{p}<0.001$ ) after treatment. Mean pre-treatment leptin concentration was $16.89 \pm 15.54 \mathrm{ng} / \mathrm{ml}$, and $21.77 \pm 14.69 \mathrm{ng} / \mathrm{ml}$ after chemotherapy (increase by $28.89 \%, \mathrm{p}<0.01$ ). A positive correlation was found between leptin concentration and age and BMI. There was no relationship of the disease severity with the response to treatment and the concentration of the adipokines. The leptin/adiponectin ratio $(\mathrm{L} / \mathrm{A})$ before treatment correlated with better response to chemotherapy.

Conclusions: Adiponectin and leptin did not correlate with the stage of ovarian cancer and response to chemotherapy. The L/A ratio may be considered a predictor of clinical response to treatment. (Endokrynol Pol 2019; 70 (1): 57-63)

Key words: adiponectin; leptin; chemotherapy; ovarian neoplasm

\section{Streszczenie}

Wprowadzenie: Rak jajnika wykrywany jest najczęściej w zaawansowanym stadium choroby. Jego patogeneza nie jest w pełni poznana, ale przyjmuje się, że odpowiedzialna jest za to podatność organizmu oraz zaburzenia hormonalne. Stale badana jest również rola niektórych cytokin jako czynników predykcyjnych w procesie leczenia. Celem pracy było określenie zależności pomiędzy stężeniem adiponektyny i leptyny a stopniem zaawansowania choroby oraz odpowiedzią na stosowaną chemioterapię.

Materiał i metody: Grupa badana składała się z 43 pacjentek leczonych systemowo z powodu raka jajnika. Po zakwalifikowaniu do leczenia pacjentki otrzymały chemioterapię: 5-7 cykli według schematu paklitaksel/karboplatyna bez bewacyzumabu lub z nim. Używając standardowych zestawów ELISA, przed chemioterapii i po niej oznaczono w surowicy krwi stężenie adiponektyny oraz leptyny.

Wyniki: Stwierdzono, że średnie stężenie adiponektyny przed chemoterapią wynosiło $8,83 \pm 3,19 \mu \mathrm{g} / \mathrm{ml}$, natomiast po zakończeniu leczenia - 10,37 $\pm 4,18 \mu \mathrm{g} / \mathrm{ml}$ (wzrost o 17,44\%; p < 0,001). Średnie stężenie leptyny przed leczeniem wynosiło 16,89 $\pm 15,54 \mathrm{ng} / \mathrm{ml}, \mathrm{na}-$ tomiast po nim $-21,77 \pm 14,69 \mathrm{ng} / \mathrm{ml}$ (wzrost o $28,89 \%$; p < 0,01). Wykazano dodatnią korelację pomiędzy stężeniem leptyny a wiekiem i wskaźnikiem masy ciała (BMI). Nie stwierdzono zależności pomiędzy stopniem zaawansowania choroby oraz odpowiedzią na leczenie a stężeniem badanych adipokin. Stwierdzono, że im mniejsza jest wartość wskaźnika leptyna/adiponektyna (L/A) przed leczeniem, tym lepszą uzyskuje się odpowiedź na zastosowaną chemioterapię.

Wnioski: Adiponektyna i leptyna analizowane oddzielnie nie korelują ze stopniem zaawansowania raka jajnika oraz odpowiedzią na chemioterapię, natomiast wartość wskaźnika L/A może być uważana jako czynnik predykcyjny odpowiedzi klinicznej na zastosowane leczenie. (Endokrynol Pol 2019; 70 (1): 57-63)
\end{abstract}

Słowa kluczowe: adiponektyna; leptyna; chemioterapia; nowotwór jajników 


\section{Introduction}

Ovarian cancer is a malignant tumour that develops mainly in peri- and postmenopausal women. Statistical data show an increase in the incidence of ovarian cancer, which varies depending on geographical regions, races, ethnic groups, economic development, and economic status of the society. On a global scale, age-standardised disease rates per 100,000 women vary from 11 in Europe, through eight in the USA, to five in selected areas of Africa or four in South America (Brazil) (http://cdn. intechopen.com). Unfortunately, ovarian cancer is most frequently detected in the advanced stage (III and IV according to the FIGO classification), which significantly reduces the chance of a complete cure. The five-year survival rate for patients in the first stage of the disease is $70-80 \%$, while in stage IV it is only $15-20 \%$ [1].

The causes of ovarian cancer are not fully understood. However, it is assumed that the most important known factors that increase its risk include genetic predisposition, white race, nulliparity, infertility, and high-fat diet. The association of obesity with the risk of developing ovarian cancer is studied [2].

Experimental animal studies and clinical observations have shown that adipose tissue is no longer treated as an energy storage. Adipocytes have been shown to be capable of synthesising and releasing a series of biologically active substances exerting auto-, para-, and endocrine effects. Among many of them, leptin, adiponectin, resistin, visfatin, and others are mentioned [3]. Interestingly, previous studies on adipokines have focused mainly on aspects related to diabetes, obesity, metabolic syndrome, cardiomyopathy, anorexia nervosa, eating disorders, or tendency for atherogenesis [4-9].

Recent reports, however, have indicated the involvement of these substances in the aetiopathogenesis of cancer, mainly breast cancer, less frequently ovarian, colorectal, gastric and prostate cancers, and others. This direction of research was inspired by the detection of the relationship between obesity and increased incidence of breast and colorectal cancer [10-12].

Using in vitro techniques, it was found that leptin may increase the proliferation and growth of ovarian cancer cell lines, activate the MAP kinase signalling pathway and inhibit tumour cell apoptosis [13]. Adiponectin exhibits opposite effects [14]. It is also suggested that the loss of leptin production capacity by tumour cells and reduced receptor expression for this protein with a simultaneous increased expression of adiponectin and its receptor may be related to cancer invasion potential [15]. Others have shown that low adiponectin levels in breast cancer patients are correlated with the occurrence of subsequent breast cancer [16]. We have previously shown that in patients with colorectal cancer subjected to palliative chemotherapy resulting in disease stabilisation (SD) or partial response (PR), the levels of adiponectin (which exert anti-inflammatory effects) are increased, and the levels of visfatin and resistin (considered to exacerbate angiogenesis and proliferation of tumour cells) are decreased [17].

In the available literature, no similar observation has been made in patients with ovarian cancer. Therefore, the aim of the study was to examine the relationship of the concentrations of adiponectin and leptin with the stage of ovarian cancer and response to the chemotherapy used.

\section{Material and methods}

The study group consisted of 43 patients treated for ovarian cancer in the Oncology Department with the Haematology Subunit of Provincial Specialist Hospital No. 3 in Rybnik. Before chemotherapy, basic laboratory and imaging investigations were performed on patients to assess the disease severity and to qualify for treatment. In addition, $2.5 \mathrm{ml}$ of blood were collected before and after chemotherapy completion, in which adiponectin and leptin levels were determined using standard ELISA kits. Patients received 5-7 cycles of chemotherapy with paclitaxel/carboplatin or paclitax$\mathrm{el} /$ carboplatin with bevacizumab (paclitaxel $175 \mathrm{mg} / \mathrm{m}^{2}$, carboplatin AUC 5-6, bevacizumab $15 \mathrm{mg} / \mathrm{kg}$ ). The criteria for inclusion in the study were:

- histopathologically confirmed ovarian cancer;

- indications for chemotherapy;

-18 to 80 years of age;

- written informed consent for participation in the study.

Exclusion criteria included lack of consent to participate in the study. After explaining the purpose and principles of the study, all individuals gave their informed and voluntary consent to be included in the study. The study was approved by the Bioethical Committee of the Medical University of Silesia, Katowice (No. KNW/022/KB1/69/12). The concentrations of adiponectin and leptin were determined in the blood serum obtained by collecting whole blood from the cubital veins in the morning on an empty stomach. After blood centrifugation at $1000 \times \mathrm{g}$ for $15 \mathrm{~min}$ at $+4^{\circ} \mathrm{C}$, the obtained serum was separated into labelled Eppendorf test tubes and frozen at $-45^{\circ} \mathrm{C}$ until assayed. Adiponectin and leptin concentrations were determined by the immunoenzymatic method using Human Adiponectin ELISA kits (BioVendor, Czech Republic) and Human Leptin ELISA (BioVendor, Czech Republic). The determinations were performed in accordance with the manufacturer's protocol. The levels of adiponectin and leptin were determined on the basis 
of a standard curve prepared for a series of dilutions available in the set of standards. Absorbance measurements in the tested samples were carried out using a Mindray MW-12A camera at $450 \mathrm{~nm}$. The sensitivity of the kit for adiponectin was $26 \mathrm{ng} / \mathrm{ml}$; intra-serial and inter-serial errors were below 3.9-5.9\% and 6.3-7.0\%, respectively. Kit sensitivity for leptin was $0.2 \mathrm{ng} / \mathrm{ml}$; intra-serial and inter-serial errors were $4.2-7.6 \%$ and $4.4-6.7 \%$, respectively.

Statistical analysis was performed in the Statistica 12 and MS Excel 2013 programs. The values calculated for quantitative variables are presented as the arithmetic mean with standard deviation (SD), median, or percentage. Statistical analysis was carried out with Kruskal-Wallis test. The Spearman test was used to assess the correlation. Statistical significance was considered at $\mathrm{p}<0.05$.

\section{Results}

A total of 43 people aged 36 to 81 years (median 62 years) took part in the study. The average body weight was $65.91 \pm 13.66 \mathrm{~kg}$, while the height was $158.55 \pm 6.25 \mathrm{~cm}$.
Body mass index (BMI) was $26.22 \pm 5.31 \mathrm{~kg} / \mathrm{m}^{2}$. The average adiponectin concentration before chemotherapy was found to be $8.83 \pm 3.19 \mu \mathrm{g} / \mathrm{ml}$, as compared to $10.37 \pm 4.18 \mu \mathrm{g} / \mathrm{ml}$ after treatment (increase by $17.44 \%$, $\mathrm{p}<0.001)$. Mean pre-treatment leptin concentration was $16.89 \pm 15.54 \mathrm{ng} / \mathrm{ml}$, compared to $21.77 \pm 14.69$ $\mathrm{ng} / \mathrm{ml}$ after treatment (increase by $28.89 \%$, p < 0.01) (Tab. I-II). After 5-7 cycles of chemotherapy, the disease was stable (SD) in $26 \%$ of the patients, partial response (PR) was observed in 30\%, and complete remission (CR) in $8 \%$. Progressive disease (PD) was noted in $9 \%$ of the patients, and patients who underwent adjuvant chemotherapy accounted for $26 \%$ (Fig. 1). A positive correlation was found between leptin concentration and age and BMI. Such a relationship was not observed in relation to leptin. The severity of the disease (FIGO classification) showed no correlation with the $\mathrm{Ca}$ 125 marker, response to the treatment used, and the concentration of adipokines tested (Tab. III, Fig. 2-5). A statistically significant correlation was found between the L/A ratio (before treatment) and treatment effects, i.e. the lower the rate the better the clinical response. Such dependence was not observed after chemotherapy

Table. I. Patients characteristics and adiponectin, and leptin levels $(n=43)$

Tabela. I. Charakterystyka pacjentów oraz stężenia adiponektyny i leptyny $(n=43)$

\begin{tabular}{|c|c|c|c|c|c|c|c|c|c|}
\hline & & $\mathbf{n}$ & $\begin{array}{l}\text { Mean } \\
\text { value }\end{array}$ & $\begin{array}{c}\text { Median } \\
\text { value }\end{array}$ & Min. & Max. & $\begin{array}{l}25^{\text {th }} \text { quartile } \\
\text { value }\end{array}$ & $\begin{array}{l}75^{\text {th }} \text { quartile } \\
\text { value }\end{array}$ & SD \\
\hline Age [years] & & 43 & 59.44 & 62.00 & 36.00 & 81.00 & 51.00 & 66.00 & 10.37 \\
\hline Weight [kg] & & 43 & 65.91 & 67.00 & 44.00 & 100.50 & 54.50 & 73.00 & 13.66 \\
\hline Height [cm] & & 43 & 158.55 & 160.00 & 142.00 & 169.00 & 154.00 & 163.00 & 6.25 \\
\hline BMI $\left[\mathrm{kg} / \mathrm{m}^{2}\right]$ & & 43 & 26.22 & 25.97 & 16.51 & 41.83 & 23.04 & 29.09 & 5.31 \\
\hline \multirow{3}{*}{$\begin{array}{l}\text { Adiponectin } \\
{[\mu \mathrm{g} / \mathrm{ml}]}\end{array}$} & Before (I) & 43 & 8.83 & 7.98 & 2.84 & 23.27 & 7.38 & 9.80 & 3.19 \\
\hline & After (II) & 43 & 10.37 & 9.47 & 3.76 & 26.71 & 7.51 & 12.34 & 4.18 \\
\hline & Subtraction (II-I) & 43 & 1.54 & 1.49 & 0.92 & 3.44 & 0.13 & 2.54 & 0.99 \\
\hline \multirow{3}{*}{$\begin{array}{l}\text { Leptin } \\
\text { [ng/ml] }\end{array}$} & Before (I) & 43 & 16.89 & 10.31 & 1.36 & 57.69 & 4.25 & 30.05 & 15.54 \\
\hline & After (II) & 43 & 21.77 & 18.85 & 1.38 & 57.07 & 7.35 & 34.70 & 14.69 \\
\hline & Subtraction (II-I) & 43 & 4.87 & 8.54 & 0.02 & -0.62 & 3.10 & 4.65 & -0.85 \\
\hline
\end{tabular}

$\mathrm{SD}$ — standard deviation; BMI — body mass index

Table II. Adiponectin and leptin plasma level in patients before and chemotherapy treatment $(n=43)$

Tabela II. Stężenie adiponektyny $i$ leptyny $w$ osoczu u chorych przed chemioterapia i po zakończeniu leczenia $(n=43)$

\begin{tabular}{|c|c|c|c|c|c|c|c|c|c|}
\hline & \multicolumn{2}{|c|}{$\begin{array}{c}\text { Before } \\
\text { chemotherapy }\end{array}$} & \multicolumn{2}{|c|}{$\begin{array}{c}\text { After } \\
\text { chemotherapy }\end{array}$} & \multirow{2}{*}{$\begin{array}{c}\text { Change } \\
(\%)\end{array}$} & \multirow{2}{*}{$\begin{array}{c}\text { Before } \\
\text { chemotherapy } \\
\text { Median }\end{array}$} & \multirow{2}{*}{$\begin{array}{c}\begin{array}{c}\text { After } \\
\text { chemotherapy }\end{array} \\
\text { Median }\end{array}$} & \multirow{2}{*}{ p value } & \multirow{4}{*}{ 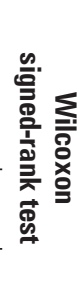 } \\
\hline & $\begin{array}{l}\text { Mean } \\
\text { value }\end{array}$ & SD & $\begin{array}{l}\text { Mean } \\
\text { value }\end{array}$ & SD & & & & & \\
\hline Adiponectin $[\mu \mathrm{g} / \mathrm{ml}]$ & 8.83 & 3.19 & 10.37 & 4.18 & 17.44 & 7.98 & 9.47 & $<0.001$ & \\
\hline Leptin [ng/ml] & 16.89 & 15.54 & 21.77 & 14.69 & 28.89 & 10.31 & 18.85 & $<0.01$ & \\
\hline
\end{tabular}

SD — standard deviation 


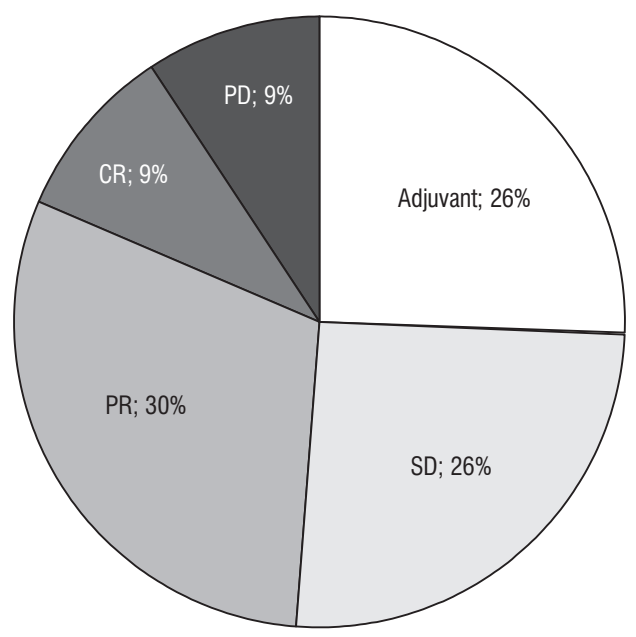

Figure 1. Clinical response to chemotherapy $(n=43)$ : $C R$ - complete response; $P R$ - partial response; $S D$ - stable disease; PD — progression disease

Rycina 1. Odpowiedź kliniczna na chemioterapię $(n=43)$; $C R$ - odpowiedź całkowita; PR - odpowiedź częściowa; $S D$ — stabilizacja choroby; PD — progresja choroby

termination (Table IV). To exclude the impact of BMI on the conclusions that have been drawn from the $\mathrm{L} / \mathrm{A}$ ratio and treatment response, additional statistics were performed, i.e. clinical responses were independent variables and BMI was a dependent variable. We showed no differences between examined groups of patients (Kruskal-Wallis test; $\mathrm{H}=4.516$; $\mathrm{p}=0.341$ ), which means that BMI was not a factor that affected the $\mathrm{L} / \mathrm{A}$ ratio and the treatment output.

\section{Discussion}

Previous studies indicate that the decreased serum concentration of adiponectin and elevated concentration of leptin are characteristic of obesity and associated with a higher risk of endometrial cancer and breast cancer [18]. In the case of ovarian tumours, the findings are ambiguous. Tessitore et al. [19] found increased levels of leptin and its mRNA in patients with ovarian cancer,

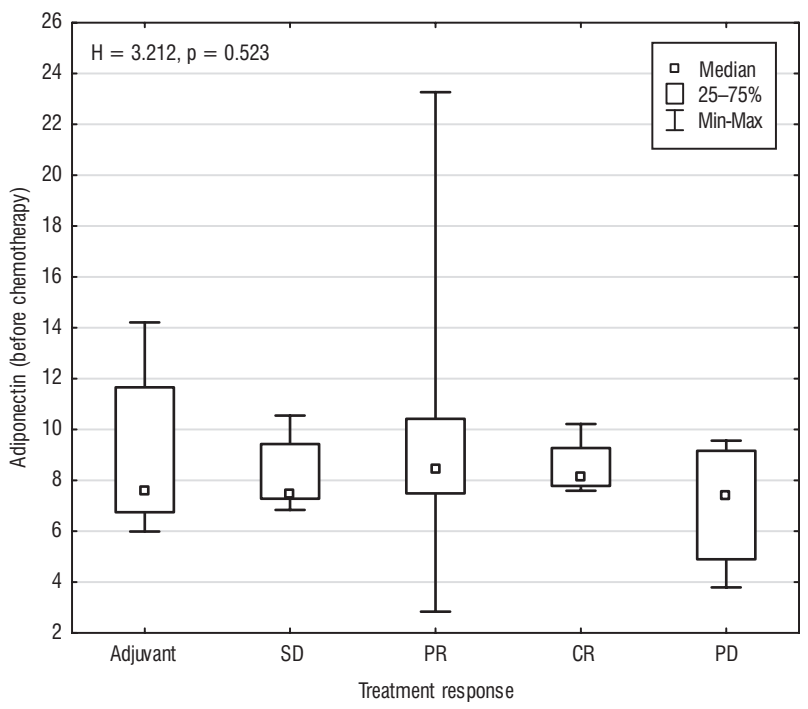

Figure 2. Adiponectin level before chemotherapy and clinical response $(n=43)$. $C R$ - complete response; $P R$ - partial response; $S D$ - stable disease; $P D$ - progression disease

Rycina 2. Stężenie adiponektyny przed chemotherapia i odpowiedź kliniczna $(n=43)$. CR — odpowiedź catkowita; $P R$ —odpowiedź częściowa; SD — stabilizacja choroby; $P D$ — progresja choroby

which was accompanied by elevated levels of FSH. The authors suggest that leptin can stimulate the production of sex hormones, whose role in the formation of female genital cancers is proven. The obtained results contrast with those reported by other authors who failed to find a significant difference in the concentration of leptin between patients with ovarian cancer and the control group (women with mild adnexal lesions) [20]. However, Jin et al. [21] analysed the concentrations of adiponectin and leptin in 52 patients with ovarian cancer, referring the results to the control group (50 women with mild disorders of the reproductive organs). They showed that both adiponectin and leptin concentrations in patients with ovarian cancer were significantly lower than in healthy subjects, i.e. 8.25 vs. $11.44 \mu \mathrm{g} / \mathrm{mL}$ and 7.09 vs. $15.4 \mathrm{ng} / \mathrm{mL}$, respectively. Interestingly, they also showed that there was no relationship between the

Table III. Leptin and adiponectin plasma level in patients according to age, BMI, FIGO staging, and CEA ( $n=43)$

Table III. Stężenie adiponektyny $i$ leptyny w osoczu u chorych w zależności od wieku, BMI, zaawansowania wg FIGO oraz CEA $(n=43)$

\begin{tabular}{|c|c|c|c|c|c|c|c|c|c|c|c|c|}
\hline & \multirow[t]{2}{*}{ Chemotherapy } & \multicolumn{2}{|c|}{ Age } & \multicolumn{2}{|c|}{ BMI } & \multicolumn{2}{|c|}{ FIGO staging } & \multicolumn{2}{|c|}{$\begin{array}{c}\text { CEA } \\
\text { (before CHTH) }\end{array}$} & \multicolumn{2}{|c|}{$\begin{array}{c}\text { CEA } \\
\text { (after CHTH) }\end{array}$} & \multirow[b]{2}{*}{ D } \\
\hline & & $\mathbf{R}$ & $p$ value & $\mathbf{R}$ & p value & $\mathbf{R}$ & $p$ value & $\mathbf{R}$ & $\mathrm{p}$ value & $\mathbf{R}$ & $\mathrm{p}$ value & \\
\hline \multirow{2}{*}{$\begin{array}{l}\text { Adiponectin }[\mu \mathrm{g} / \\
\mathrm{ml}]\end{array}$} & Before & -0.103 & 0.508 & -0.234 & 0.131 & 0.066 & 0.673 & -0.580 & 0.708 & - & - & \\
\hline & After & 0.022 & 0.890 & -0.005 & 0.974 & -0.040 & 0.798 & - & - & -0.259 & 0.093 & 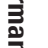 \\
\hline \multirow{2}{*}{ Leptin [ng/ml] } & Before & 0.301 & $<0.05$ & 0.491 & $<0.05$ & -0.172 & 0.269 & -0.121 & 0.437 & - & - & \\
\hline & After & 0.335 & $<0.05$ & 0.563 & $<0.05$ & -0.011 & 0.942 & - & - & -0.038 & 0.804 & \\
\hline
\end{tabular}

CHTH — chemothetrapy; BMI — bod mass index; FIGO — The International Federation of Gynecology and Obstetrics; CEA — carcinoembryonic antigen 


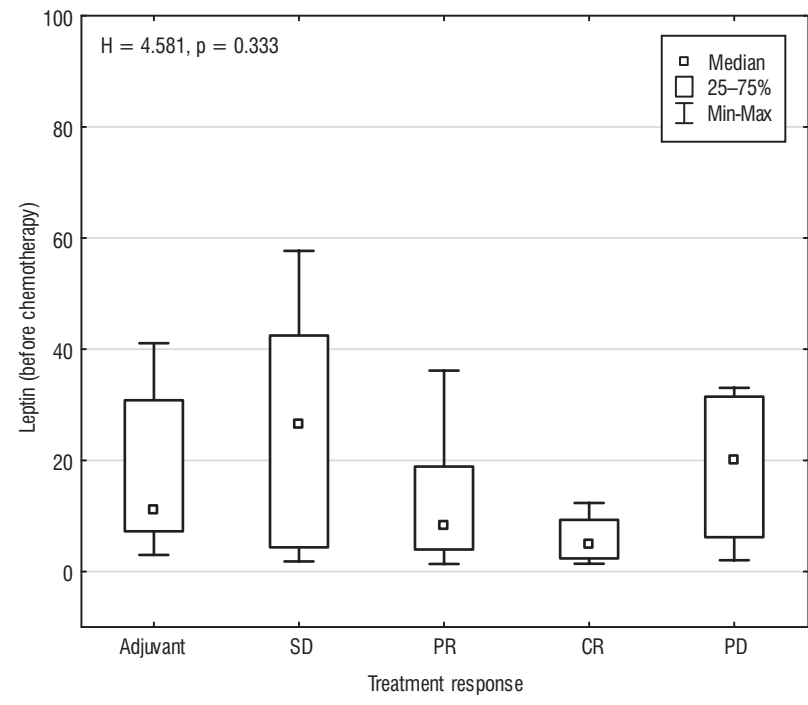

Figure 3. Leptin level before chemotherapy and clinical response $(n=43) . C R$ - complete response; $P R$ - partial response; $S D$ — stable disease; $P D$ - progression disease

Rycina 3. Stężenie leptyny przed chemotherapia $i$ odpowiedź kliniczna $(n=43)$. CR - odpowiedź całkowita; PR - odpowiedź częściowa; SD — stabilizacja choroby; $P D$ — progresja choroby

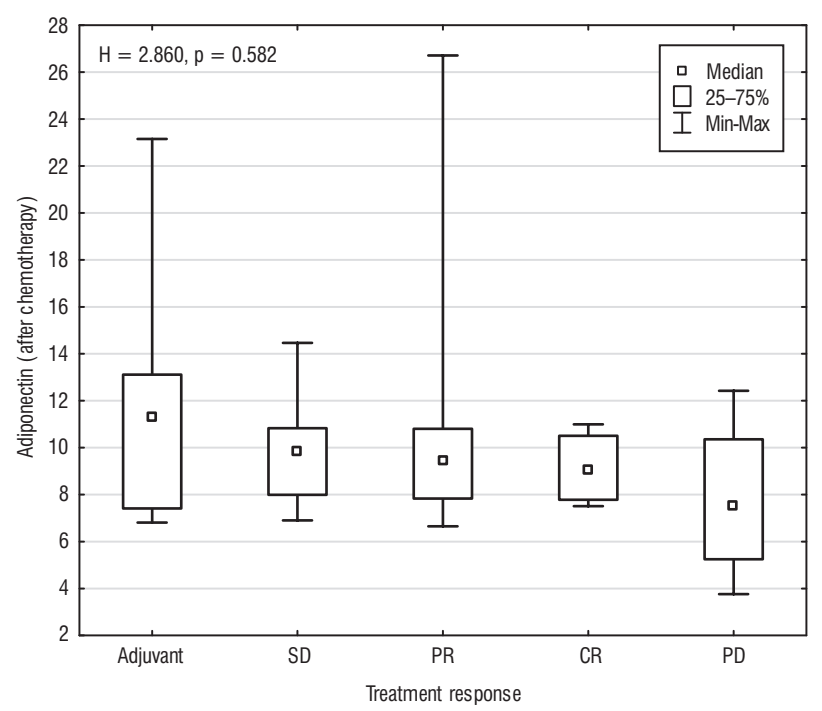

Figure 4. Adiponectin level after chemotherapy and clinical response $(n=43)$. $C R$ - complete response; $P R$ - partial response; $S D$ — stable disease; $P D$ — progression disease

Rycina 4. Stężenie adiponektyny po chemotherapii i odpowiedź kliniczna $(n=43)$. CR - odpowiedź całkowita; PR —odpowiedź częściowa; SD — stabilizacja choroby; PD — progresja choroby

concentration of adipokines and the disease severity (according to the FIGO classification), which is in line with the results of the current study. Others in a cohort study of patients with ovarian cancer concluded that leptin positively correlated with BMI, although no such correlation was noted for adiponectin (as in the current study). Using Kaplan-Meyer survival curves, the

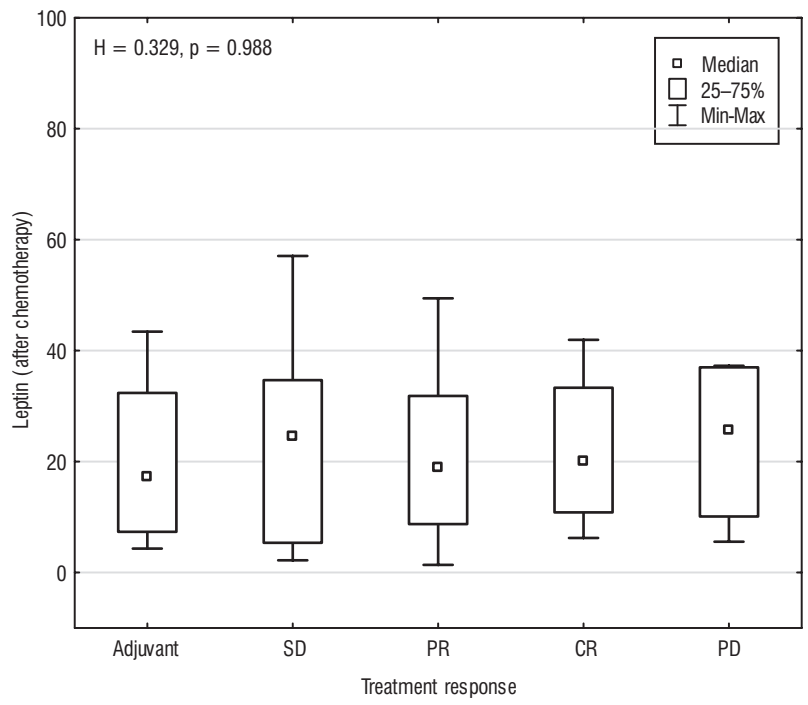

Figure 5. Leptin level after chemotherapy and clinical response $(n=43) . C R-$ complete response; $P R$ - partial response; $S D$ — stable disease; $P D$ - progression disease

Rycina 5. Stężenie leptyny po chemotherapiq $i$ odpowiedź kliniczna $(n=43)$. CR — odpowiedź catkowita; $P R$ —odpowiedź częściowa; SD — stabilizacja choroby; PD — progresja choroby

authors cited showed that patients with low leptin/adiponectin (L/A) ratio had statistically longer survival times (57 months) than those with higher L/A ratio (49 months) [22]. In the present study we found a statistically significant correlation between the L/A ratio (before treatment) and the effects of treatment, i.e. the lower the ratio, the better the clinical response. Such a correlation was not observed after chemotherapy termination. Grabowski [23], who recruited 70 patients to his study, 42 with ovarian cancer and 28 with mild adnexal lesions (control), observed lower levels of leptin in patients with ovarian cancer than in the control group. The analysis in the group of patients with ovarian cancer showed that the mean leptin concentration was significantly higher in patients with lower stages of advancement, i.e. stage I and II as compared to stage III and IV. These results contrast with our current findings, which revealed no correlation between the disease severity and leptin concentration (similar results were obtained by Jin et al. [21]). Worthy of note is also the disproportion in the number of study subjects in groups (statistical limitations) - in our study patients with I and II FIGO accounted only for $12 \%$ (five women), whereas in the study conducted by Grabowski it amounted to $29 \%$ (12 women). Interestingly, Grabowski also observed that leptin concentration significantly increased after termination of treatment (chemotherapy), from $11.725 \pm 10.497 \mathrm{ng} / \mathrm{ml}$ to $17.940 \pm 11.193 \mathrm{ng} / \mathrm{ml}$ (increase by $53 \%$ ), which is consistent with the results of our research $(16.89 \pm 15.54 \mathrm{ng} / \mathrm{ml}$ vs. $21.77 \pm 14.69$, an increase of $29 \%$ ). Previously, we also showed that in 
Table IV. Leptin/adiponectin ratio $(L / A)$ and clinical response $(n=43)$

Table IV. Wskaźnik leptyna/adipokina $(L / A)$ i odpowiedź kliniczna $(n=43)$

\begin{tabular}{|c|c|c|c|c|c|c|c|c|c|c|c|c|}
\hline \multirow{2}{*}{$\begin{array}{l}\text { Adipokines } \\
\text { ratio }\end{array}$} & \multirow{2}{*}{$\begin{array}{l}\text { Clinical } \\
\text { response }\end{array}$} & \multicolumn{2}{|c|}{ CR } & \multicolumn{2}{|c|}{ PR } & \multicolumn{2}{|c|}{ SD } & \multicolumn{2}{|c|}{ PD } & \multirow[b]{2}{*}{$\mathbf{R}$} & \multirow[b]{2}{*}{ p value } & \multirow{4}{*}{ 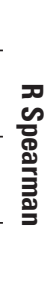 } \\
\hline & & Value & $\begin{array}{l}\text { Standard } \\
\text { deviation }\end{array}$ & Value & $\begin{array}{l}\text { Standard } \\
\text { deviation }\end{array}$ & Value & $\begin{array}{l}\text { Standard } \\
\text { deviation }\end{array}$ & Value & $\begin{array}{l}\text { Standard } \\
\text { deviation }\end{array}$ & & & \\
\hline \multirow{2}{*}{ L/A } & $\begin{array}{l}\text { Before } \\
\text { chemotherapy }\end{array}$ & 0.69 & 0.57 & 1.75 & 1.99 & 3.09 & 2.60 & 3.32 & 3.31 & -0.369 & $<0.05$ & \\
\hline & $\begin{array}{l}\text { After } \\
\text { chemotherapy }\end{array}$ & 2.48 & 1.95 & 2.11 & 1.53 & 2.40 & 1.79 & 3.90 & 4.02 & -0.188 & 0.302 & \\
\hline
\end{tabular}

CR — complete response; PR — partial response; SD — stable disease; PD — progression disease

patients with colorectal cancer the levels of adiponectin and leptin increased, although this applied only to patients with partial response (PR) and stable disease (SD), but not to patients with progressive disease (PD) [24]. While the increase in adiponectin levels seems to be beneficial because it is believed to have antiproliferative and anti-angiogenic properties [25-27], the increase in leptin may be difficult to interpret. It is known that leptin binds to specific leptin receptors (LEPR), which leads to the activation of signalling pathways of MAP kinases (p38 and ERK1/2) and JAK/STAT pathways [28]. As mentioned in the introduction, in vitro models have shown that leptin may increase the proliferation and growth of ovarian cancer cell lines, activate the MAP kinase signalling pathway, and inhibit tumour cell apoptosis [13]. The clinical references for these studies are the observations made by Kumar et al. [29], who did not find differences in survival between patients with high and low leptin expression or high and low LEPR expression in tumour tissue. However, patients who had higher (more than median) co-expression of leptin and LEPR (in tumour tissue) had significantly shorter survival. Therefore, when determining the role of adipokines in the process of neoplasia, tumour microenvironment should be looked at more closely, whereas serum adipokines (in cancer patients) should be assessed rather in the aspect of the impact of proinflammatory cytokines (secreted by tumour tissue, e.g. TNF, interleukin-1, interleukin-6) on the body's metabolism and hormonal activity of adipose tissue [30]. It seems that tumour mass reduction under the influence of chemotherapy results in reduced release of various proinflammatory cytokines, which can also change the endocrine function of adipose tissue, including the secretion of adipokines.

\section{Conclusions}

Adiponectin and leptin analysed separately do not correlate with the stage of ovarian cancer and response to chemotherapy. However, the L/A ratio may be considered a predictor of clinical response to treatment.

\section{Acknowledgements}

This work was supported by grant no. KNW-1-008/N/6/0 from the Medical University of Silesia in Katowice, Poland.

The study was approved by the Bioethical Committee of Medical University of Silesia, Katowice (No. KNW / 022 / KB1 / 69/12).

\section{References}

1. Romanidis K, Nagorni EA, Halkia E, et al. The role of cytoreductive surgery in advanced ovarian cancer: the general surgeon's perspective. J BUON. 2014; 19(3): 598-604, indexed in Pubmed: 25261641.

2. Kalliala I, Markozannes G, Gunter MJ, et al. Obesity and gynaecological and obstetric conditions: umbrella review of the literature. BMJ. 2017; 359: j4511, doi: 10.1136/bmj.j4511, indexed in Pubmed: 29074629.

3. Rondinone CM. Adipocyte-derived hormones, cytokines, and mediators. Endocrine. 2006; 29(1): 81-90, doi: 10.1385/ENDO:29:1:181, indexed in Pubmed: 16622295.

4. Achari AE, Jain SK. Adiponectin, a Therapeutic Target for Obesity, Diabetes, and Endothelial Dysfunction. Int J Mol Sci. 2017; 18(6), doi: 10.3390/ijms18061321, indexed in Pubmed: 28635626.

5. Oswiecimska JM, Roczniak W, Roczniak RG, et al. Serum adiponectin levels in adolescents and young adults with growth hormone deficiency. Neuro Endocrinol Lett. 2017; 38(2): 107-116, indexed in Pubmed: 28650604

6. Wojciechowska C, Jacheć W, Romuk E, et al. The effect of BMI, serum leptin, and adiponectin levels on prognosis in patients with non-ischaemic dilated cardiomyopathy. Endokrynol Pol. 2017; 68(1): 26-34, doi: 10.5603/EP.2017.0005, indexed in Pubmed: 28255978.

7. Baranowska-Bik A, Baranowska B, Martyńska L, et al. Adipokine profile in patients with anorexia nervosa. Endokrynol Pol. 2017; 68(4): 422-429, doi: 10.5603/EP.a2017.0035, indexed in Pubmed: 28604943.

8. Krysiak R, Żmuda W, Marek B, et al. Age may determine the effect of hypolipidemic agents on plasma adipokine levels in patients with elevated low-density lipoprotein cholesterol levels. Endokrynologia Polska. 2015, doi: 10.5603/ep.a2016.0019.

9. Ziora-Jakutowicz K, Zimowski J, Ziora KT, et al. Genetic polymorphisms and serum concentrations of adiponectin and resistin in anorexia nervosa and healthy controls - pilot study. Neuro Endocrinol Lett. 2017; 38(3): 215-223, indexed in Pubmed: 28759190.

10. Stoll BA. Obesity and breast cancer. Int J Obes Relat Metab Disord. 1996; 20(5): 389-392, indexed in Pubmed: 8696416.

11. Bianchini F, Kaaks R, Vainio H. Overweight, obesity, and cancer risk. Lancet Oncol. 2002; 3(9): 565-574, indexed in Pubmed: 12217794.

12. Siemińska L, Borowski A, Marek B, et al. Serum concentrations of adipokines in men with prostate cancer and benign prostate hyperplasia. Endokrynol Pol. 2018; 69(2): 120-127, doi: 10.5603/EP.a2018.0006, indexed in Pubmed: 29465157.

13. Choi JH, Park SH, Leung PCK, et al. Expression of leptin receptors and potential effects of leptin on the cell growth and activation of mitogen-activated protein kinases in ovarian cancer cells. J Clin Endocrinol Metab. 2005; 90(1): 207-210, doi: 10.1210/jc.2004-0297, indexed in Pubmed: 15522945 .

14. Schäffler A, Schölmerich J, Buechler C. Mechanisms of disease: adipokines and breast cancer - endocrine and paracrine mechanisms that connect adiposity and breast cancer. Nat Clin Pract Endocrinol Metab. 2007; 3(4): 345-354, doi: 10.1038/ncpendmet0456, indexed in Pubmed: 17377617.

15. Jeong YJ, Bong JG, Park SH, et al. Expression of leptin, leptin receptor, adiponectin, and adiponectin receptor in ductal carcinoma in 
situ and invasive breast cancer. J Breast Cancer. 2011; 14(2): 96-103, doi: 10.4048/jbc.2011.14.2.96, indexed in Pubmed: 21847403.

16. Macis D, Gandini S, Guerrieri-Gonzaga A, et al. Prognostic effect of circulating adiponectin in a randomized $2 \times 2$ trial of low-dose tamoxifen and fenretinide in premenopausal women at risk for breast cancer. J Clin Oncol. 2012; 30(2): 151-157, doi: 10.1200/JCO.2011.35.2237, indexed in Pubmed: 22162577.

17. Słomian G, Świętochowska E, Malinowska-Borowska J, et al. Association between chemotherapy and plasma adipokines in patients with colorectal cancer. Pharmacol Rep. 2014; 66(5): 902-907, doi: 10.1016/j. pharep.2014.05.015, indexed in Pubmed: 25149999.

18. Booth A, Magnuson A, Fouts J, et al. Adipose tissue, obesity and adipokines: role in cancer promotion. Horm Mol Biol Clin Investig. 2015; 21(1): 57-74, doi: 10.1515/hmbci-2014-0037, indexed in Pubmed: 25781552

19. Tessitore L, Vizio B, Pesola D, et al. Adipocyte expression and circulating levels of leptin increase in both gynaecological and breast cancer patients. Int J Oncol. 2004; 24(6): 1529-1535, indexed in Pubmed: 15138597.

20. Serin IS, Tanriverdi F, Yilmaz MO, et al. Serum insulin-like growth factor (IGF)-I, IGF binding protein (IGFBP)-3, leptin concentrations and insulin resistance in benign and malignant epithelial ovarian tumors in postmenopausal women. Gynecol Endocrinol. 2008; 24(3): 117-121, doi: 10.1080/09513590801895559, indexed in Pubmed: 18335323.

21. Jin JH, Kim HJ, Kim CY, et al. Association of plasma adiponectin and leptin levels with the development and progression of ovarian cancer Obstet Gynecol Sci. 2016; 59(4): 279-285, doi: 10.5468/ogs.2016.59.4.279, indexed in Pubmed: 27462594.

22. Diaz ES, Karlan BY, Li AJ. Obesity-associated adipokines correlate with survival in epithelial ovarian cancer. Gynecol Oncol. 2013; 129(2): 353-357, doi: 10.1016/j.ygyno.2013.02.006, indexed in Pubmed: 23402904.
23. Grabowski J. Ocena stężeń leptyny w surowicy krwi chorych na raka jajnika a skuteczność cytoredukcji i chemioterapii. Uniwersytet Medyczny im. Karola Marcinkowskiego w Poznaniu, Poznań 2009.

24. Słomian G, Świętochowska E, Nowak G. Chemotherapy and plasma adipokines level in patients with colorectal cancer. Postepy Hig Med Dosw. 2017; 71: 281-290.

25. Dalamaga M, Karmaniolas K, Papadavid E, et al. Elevated serum visfatin/nicotinamide phosphoribosyl-transferase levels are associated with risk of postmenopausal breast cancer independently from adiponectin, leptin, and anthropometric and metabolic parameters. Menopause. 2011; 18(11): 1198-1204, doi: 10.1097/gme.0b013e31821e21f5, indexed in Pubmed: 21712732

26. Dalamaga M, Archondakis S, Sotiropoulos G, et al. Could serum visfatin be a potential biomarker for postmenopausal breast cancer? Maturitas. 2012; 71(3): 301-308, doi: 10.1016/j.maturitas.2011.12.013, indexed in Pubmed: 22261365.

27. Dalamaga M, Diakopoulos KN, Mantzoros CS. The role of adiponectin in cancer: a review of current evidence. Endocr Rev. 2012; 33(4): 547-594, doi: 10.1210/er.2011-1015, indexed in Pubmed: 22547160.

28. Wauman J, Tavernier J. Leptin receptor signaling: pathways to leptin resistance. Front Biosci (Landmark Ed). 2011; 16: 2771-2793, indexed in Pubmed: 21622208

29. Kumar J, Fang H, McCulloch DR, et al. Leptin receptor signaling via Janus kinase 2/Signal transducer and activator of transcription 3 impacts on ovarian cancer cell phenotypes. Oncotarget. 2017; 8(55): 93530-93540, doi: 10.18632/oncotarget.19873, indexed in Pubmed: 29212170.

30. Patel HJ, Patel BM. TNF- $\alpha$ and cancer cachexia: Molecular insights and clinical implications. Life Sci. 2017; 170: 56-63, doi: 10.1016/j. lfs.2016.11.033, indexed in Pubmed: 27919820. 